\title{
Effect of Teaching Fundamental Movement Skills with an Inquiry-Based Instructional Model on Perceived Motor Competence
}

\author{
Meral Demir \\ Graduate School of Health Sciences, Physical Education and Sport Doctoral Program \\ Manisa Celal Bayar University, Manisa, Turkey \\ Tel: 90-236-236-0989 E-mail: mrltmr@windowslive.com \\ Mümine Soytürk (Corresponding author) \\ Faculty of Sport Sciences, Manisa Celal Bayar University \\ Halil Erdoğan Cd. Ahmet Bedevi Mah. 45040, Manisa, Turkey \\ Tel: 90-506-781-3363Ｅ-mail: soyturkmumine@gmail.com
}

\author{
Özden Tepeköylü Öztürk \\ Faculty of Sport Sciences, Pamukkale University \\ Kınıklı Kamüsü, 20100, Denizli, Turkey \\ Tel: 90-258-296-1277 E-mail: otepekoylu@hotmail.com
}

Received: December 2, 2020 Accepted: December 31, 2020

Published: January 5, 2021

doi:10.5296/jei.v6i2.18042 URL: https://doi.org/10.5296/jei.v6i2.18042

\begin{abstract}
The aim of this study is to investigate the effect of inquiry-based instruction in the teaching of fundamental movement skills to fifth-grade students on the children's perceived motor competence. Utilizing a post-test experimental design with control group, the study was carried out with 260 fifth-grade students studying in ten different classes at five different schools located in the city centre of Manisa during the 2019-2020 academic year. For collection of the data, the "Perceived Motor Competence Questionnaire in Childhood"
\end{abstract}


(PMC-C), and a "Personal Information Form" (PIF) developed by the researchers, were used. To test the effectiveness of the quasi-experimental process in the post-test design with control group, t-test was used. In the inquiry-based instruction in the teaching of fundamental movement skills of the students, a statistically significant difference was found in favour of the experimental group in the subscales of perceived motor competence. Regarding the gender variable of the students, a statistically significant difference was found between female and male students in favour of boys in the subscales of fundamental motor skills. In conclusion, it can be said that the inquiry-based instructional model was more effective than the direct instructional model in developing the fundamental motor skills of "locomotor skills" and "object control skills". Moreover, when evaluated in terms of gender, male students benefited more from the inquiry-based instructional model in terms of "object control skills".

Keywords: Inquiry-based instructional model, Fundamental movement skills, Perceived motor competence

\section{Introduction}

The experiences that children gain by using their bodies are very important for their perception and recognition of the world. Especially in the first years of life, the experiences that are gained form the infrastructure of motor development, social-emotional development and cognitive development (Bayhan \& Artan, 2009). With regard to all these areas of development, motor skills play an important role in individuals' lifelong development from childhood onwards (Hürmeriç Altunsöz \& Mülazımoğlu Ballı, 2017). In this context, the term "motor skills" generally expresses skills in which the result of both movement and action is stressed (Newell, 1991). Basic motor skills are separated into three groups according to their characteristics. These are balance skills, locomotor skills and object control skills (Gallahue, 1976). The basic motor skills assist children in controlling their bodies, forming more complex skills, and performing movement patterns in sport and other enjoyable activities (Payne \& Isaacs, 2002; Seefeldt, 1980, as cited in Gül, 2012).

The identification, and consequently, the development of children's motor skills in the first stage of adolescence is regarded as an important subject area in education, and numerous studies have been made on the subject. In this context, various measurement tools have also been developed for the measurement of motor skills. Motor skills can be measured in two ways, namely, directly by measuring physical parameters, and indirectly with questionnaires in which people's perceptions are examined (Berigel, 2015; Demirci \& Toptaş Demirci, 2016; Ulutaş et al., 2017; Gürker Tepe, 2018; Duman, 2019, Çayır, 2019). These measurement tools have generally been developed in different countries and are measurement tools that have been adapted to Turkish. In the current literature, it is determined that ten motor skills measurement tools are used in our country (Sevimay, 1986; Mülazımoğlu Ballı, 2006; Tepeli, 2007; Boz \& Güngör Aytar, 2012; Kılıç et al., 2017; Köse, 2018; Taştepe \& Köksal Akyol, 2018; Özkara \& Kalkavan, 2018; Karatel, 2019; Mülazımoğlu Ballı \& Hürmeriç Altunsöz, 2019). When different studies alongside measurement tool development studies are examined, it is seen that for positive guidance of children towards development of basic motor skills, the 
importance of successful interventions is also emphasized (Livonen \& Saakslahti, 2014), since in the conducted studies, it is stated that children with good levels of motor competence and/or positive motor competence perceptions are physically active, and that their health-related parameters (such as body mass index, aerobic capacity and strength) are positively developed. On the other hand, it is seen that in children with low motor competence, their levels of physical activity are also inadequate (Stodden et al., 2008; Wrotniak et al., 2006). When the relationships between motor development and the other areas of development are examined, it is revealed that increasing children's mobility positively supports not only their motor development, but also all areas of development. In this context, when examining the education programmes of developing countries for getting ahead in the information race, especially in recent years, it is seen that they are directed towards education programmes that place the student at the centre (student-centred), and in which high-level cognitive processes are included (Tatar, 2006). Physical education classes that ensure direct and indirect effects on motor skills and support all-round development are also of importance as an effective tool in education programmes. In this sense, it is necessary to plan physical education lessons, just as it is in all subjects, according to children's needs and to prepare them in accordance with their levels of development (Morgan et al., 2013, cited in Hürmeriç Altunsöz \& Mülazımoğlu Ball1, 2017). With the aim of educating contemporary individuals, a new curriculum was put into practice by the Ministry of National Education (MEB) in our country in 2018. This was designed in a flexible structure with an approach that places the student at the centre, and priority was given to the education of individuals who can act by thinking and feeling (MEB, 2018). Developing high-level thinking skills (analysis, synthesis and evaluation), fostering knowledge acquisition methods in students, suggesting and testing new ideas, fostering individual learning responsibility and academic skills, and enabling mental assimilation and exchange of information can all be realised through inquiry-based learning, which is one of the innovative educational practices in physical education classes (Lim, 2001, cited in Fansa, 2012; Throwbridge et al., 2004, cited in Parim, 2009; Kula, 2009).

\subsection{Context of and Aim of Study}

Regarding the model-based approach, which is seen as a means of crossing the boundaries imposed by the traditional approach to physical education (Kirk, 2013), the consensus of support has been increasing for a long time with regard to model-based practices being a potential implementation in physical education in the future (Casey, Goodyear, \& Dyson, 2015; Casey \& Dyson, 2009). In parallel with this, in our country, too, model-based physical education practices are becoming increasingly widespread (Alagül \& Gürsel, 2019; Filiz, 2019; Asma \& Soytürk, 2018; Doydu, Çelen, \& Çoknaz, 2013; Soytürk, Birsen, \& Çamlıyer, 2017). One of these models is the inquiry-based instructional model (RBIM), which enables a holistic learning approach in terms of development areas by guiding students towards inquiry and investigation. In the model, skills such as observation, experimentation, classification, hypothesis development, deduction, design and planning are used for inquiry in the learning process (Østergaard, 2016). By intensive involvement of students, inquiry-based instruction makes a significant contribution to achieving the aims of basic education. By means of 
fundamental investigation and discovery of new facts, students learn critical thinking and how to solve problems (Dostál, 2015). As well as including active learning processes such as problem-based learning, learning by discovery, and project-based learning, the inquiry-based learning environment can be defined as an environment in which students can learn by exploring scientific concepts and in which they are presented with questions, problems and tasks (Hammer, 1997, cited in Akpullukçu, 2011). For this reason, the conducted studies cannot be gathered under a single heading. İnquiry-based learning is a method which directs students towards research by combining their existing knowledge with new information, and in which the teacher is a guide within the process (Friedl \& Koontz, 2005, as cited in Altunsoy, 2008). It is a process in which students are actively involved in activities, experiments and discoveries, in which they themselves are responsible for their own learning, and which enables knowledge to be meaningful and permanent in the sense that they apply their learning to daily life (Çalışkan, 2009; Tatar, 2006). The inquiry-based learning model is a means of interrogation, searching for knowledge, and creating something new regarding a phenomenon (NSES, 2000). The most important positive benefit of this model is students' need to process information cognitively in their minds before expressing it through movement. Therefore, teachers must ask questions to enable students to think about possible answers, and they must give students time to put these responses into action. In other words, the main theme of this model is that the student is given a problem-solving task (Bulca, 2017). In Turkey, investigation of the effectiveness, contents and application methods of motor skills programmes implemented at secondary school level will serve as a guide for programmes to be implemented in the future. Moreover, the use of the inquiry-based learning model in the instruction process will form the basis for educating individuals who are more inquiring, critical, problem-solving and creative, that is, who meet the requirements of universal life. It is expected that this study, which has not previously been conducted in Turkey in the field of physical education and sports lessons, will encourage both other researchers and implementers. Therefore, the aim of this study is to investigate the effect of inquiry-based instruction in the teaching of fundamental movement skills to fifth-grade students on the children's perceived motor competence. Moreover, in this process, the sub-aim of the study is to reveal differences between genders.

\subsection{Research Question}

The question that guided this study was: Does inquiry-based teaching have an effect on children's perceived motor competence in teaching fifth grade student's basic movement skills?

\section{Method}

\subsection{Participant (Subject) Characteristics}

The participants of the study consisted of 260 fifth-grade students studying in ten different classes at five different schools located in the city centre of Manisa during the autumn term of the 2019-2020 academic year. The students were determined by choosing two classes from each school whose lessons were conducted by the same physical education teacher. One of these classes was assigned as the experimental group, the other as the control group. There 
were 134 students in the experimental group $\left(\mathrm{x}_{(\mathrm{age})}=10.66 \pm .474\right)$ and 126 students in the control group $\left(\mathrm{x}_{(\mathrm{age})}=10.57 \pm .497\right)$. Students' ages ranged between 10 and 11. When evaluated in terms of gender, 140 girls $(53.8 \%)$ and 120 boys $(46.2 \%)$ were included in the study.

\subsection{Sampling Procedures}

The research was carried out within the framework of the Cooperation in Education Protocol, which is valid between 2019-2022, signed between Manisa Celal Bayar University and Manisa Directorate of National Education. Students studying in two class of fifth grade at schools with volunteer teachers were included in the study on a voluntary basis. A purposeful sampling method was used for the sampling.

\subsection{Data Collection Tools}

In order to assess participants' perceived motor competence in the study, the "Perceived Motor Competence Questionnaire in Childhood" (PMC-C), developed by Dreiskaemper et al. (2018) and adapted to Turkish by Mülazımoğlu Ballı and Hürmeriç Altunsöz (2018), and a "Personal Information Form" (PIF) developed by the researchers, were used.

\subsubsection{Perceived Motor Competence Questionnaire in Childhood (PMC-C)}

The PMC-C, which was used to gather data in the research, is a 24-item, 4-point Likert-type measurement tool. The scale has two sub-dimensions, namely "locomotor skills" and "object control skills". While the locomotor skills sub-dimension consists of the factors of running, hopping, jumping and leaping, the object control skills sub-dimension comprises the factors of catching, kicking, throwing and bouncing. The Cronbach alpha values were determined to be .90 for the locomotor skills sub-dimension, .87 for the object control skills sub-dimension, and .77 for the whole scale.

For the current study, however, the Cronbach alpha values were determined as .82 for the locomotor skills sub-dimension, .87 for the object control skills sub-dimension, and .88 for the whole scale.

\subsubsection{Personal Information Form (PIF)}

In the study, information on gender, age and class was obtained with the "Personal Information Form".

\subsection{Research Process}

In line with the aim of the study, the fifth-grade learning outcomes in the curriculum set by the Ministry of National Education were examined, and four outcomes included in the "Motor Skills" sub-domain of the "Motor Competence" learning domain were specified. These are:

PE.5.1.1.1. Performs locomotor movements by showing awareness of space and effort.

PE.5.1.1.2. Performs balance movements by showing awareness of body and space. 
PE.5.1.1.3. Performs object control movements by showing body awareness and displaying movement relationships.

PE.5.1.1.4. Displays combined movement skills in various games and activities.

In line with these outcomes, first of all, the lesson plans were prepared. The lesson plans were created by 1 physical education teacher (1st researcher), who is one of the researchers of this study, and 1 faculty member who has conducted studies in the field of physical education and sport. The physical education teacher has 20 years of professional experience and is proceeding with doctoral education in the field of physical education and sport. The faculty member conducts classes at university level related to school experience, and teaching methods and techniques in physical education, and has published scientific studies in this field. While determining the questions, techniques and details used in the lesson content in accordance with the RBIM, the Bulca (2017) resource was also utilised. Next, the schools in which the experimental implementation was to be conducted were determined, and meetings were held with the administrators and physical education teachers of five different schools. After permission had been obtained from the school administrators, and with the aim of giving the teachers information about the detailed content of the research, implementation process and instruction to be given to the teachers, a separate meeting was held with the physical education teachers who were to conduct the experimental implementation. The implementing teachers were all included in the research on a voluntary basis and took part in all training sessions. The study was carried out with a total of 5 physical education teachers, with 1 physical education teacher from each school. A meeting was held with fifth-grade students who showed willingness to participate voluntarily in the research, and their parents. At this meeting, subjects such as the detailed content of the study, potential benefits, participation in the research, withdrawal from the research, and responsibilities of the participants were clarified. Two classes from each school who had physical education lessons on two different days were assigned, one as the experimental group and the other as the control group. While the assignments were made, the physical education teachers' class schedules were taken into consideration. The material resources of the schools where the implementation was to be made were also examined. The suitability of the lesson plan content and school resources were assessed and the necessary arrangements were made. Insufficient material resources regarded as necessary were supplied by the researchers. Since none of the schools had a sports hall or suitable indoor area, the exercises were performed in the schoolyard. The lesson plans prepared by the experts were conveyed and explained to the teachers, whose questions were answered. In case of any questions or problems that might occur during the implementation process, one of the researchers was present at the schools where the study was conducted and provided support and feedback. Physical education lessons with the inquiry-based instructional model were taught during normal lesson times once a week for two lesson hours over a period of six weeks. The experimental process was carried out during the autumn term of the 2019-2020 academic year.

\subsubsection{Specifying the Teachers}

In order to contribute to the sustainability of the research and to better understand the 
applicability of the model in the teaching-learning process, the suitability of having the practices in the scope of the research conducted by the participants' physical education teachers was decided by the researchers. Therefore, physical education teachers in schools located close to each other and with similar socio-cultural characteristics were included in the research as implementers. Preliminary interviews were held with these teachers, and the content and details of the study were explained. Following the preliminary interviews, teachers who were willing to participate were included in the research. During the preliminary interviews, the physical education teachers were also asked whether they had received any training or information related to any model-based instruction within the training they had received. It was determined that they had received no training or information regarding any model-based instruction. Each of the five teachers had graduated from the same physical education and sport department of the same university, and had studied the same curriculum. Teachers who had graduated before the year 2010 had at least 10-15 years of professional experience. Therefore, it was considered that knowledge and educational approaches related to movement training would show similarity. Furthermore, to keep the teacher effect at a similar level, the teachers were given 18 hours of training related to teaching fundamental movement skills with the inquiry-based instructional model.

\subsubsection{Training for the Inquiry-Based Instructional Model}

With the aim of enabling the teachers to use the "inquiry-based instructional model" (RBIM) for fostering the fifth-grade outcomes related to fundamental movement skills in the subjects of the curriculum published by the Ministry of National Education (MEB, 2018), to allow the teachers to follow a similar path in the instruction process despite working at different schools, and for the subject content to conform to the daily plan given to them by the facilitators (trainers of trainers), and for the topics to be taught in a synchronised order, first of all theoretical, then practical training related to the use of the RBIM in the teaching of basic skills was given by the researchers. The training was given for two hours a day for three days a week over a period of three weeks. The training consisted of three sections:

(a) Introduction to the training, information related to the programme and information on basic skills instruction.

(b) Implementation of the RBIM during basic skills instruction (e.g., for the basic skill of running: "Which is the fastest-running animal?" "What kind of running styles are there?" "Before beginning to run, what kind of position should we take up so that we can run faster? Let's try this out.").

(c) Assessment carried out during and after training ("How was the rhythm of the 'running' skill we learned in our lesson today?" "How should the rhythm and frequency of steps be during slow, medium and fast running?" "We have also tried out very fast running; during this running, when which part of our foot touched the ground was our speed not reduced?" "For our next lesson, who is the fastest-running athlete, and how does he use his body while running? Investigate." "Similarly, what is the longest running distance, what is it called, and who broke the world record? Investigate."). 
After the training period was completed, interaction was maintained with the teachers at the implementation schools throughout the process, support was given, and their questions were answered.

\subsubsection{Content Applied in Experimental and Control Groups}

Daily plans explaining in detail the content of the lesson to be taught to the experimental group were given to the physical education teachers each week at least two days in advance, and the necessary explanations were made. Each week, for each subject content included in the daily plan, activities covering 2-3 basic skills topics (walking, leaping, running, hopping, changing direction, etc.) were included. At the practice stage of these skills, implementation of the lesson content in accordance with the aim of the research was supported with the use of numerous accessories, such as rhythm tools (whistle, drum, goblet drum, etc.), rope, hoops and funnels. Moreover, before beginning the lesson, an attempt was made to achieve the targeted goal of the lesson by enabling students to obtain information from their teachers regarding the lesson content and to ask questions related to the inquiry-based instructional model (e.g., "how does a rabbit hop?"). The lessons in the control group class, however, were taught only with the command style in direct instruction with a traditional educational structure. In each school, the same physical education teacher conducted the lessons of the specified experimental and control groups.

Table 1. Example of use of inquiry-based instructional model in teaching of fundamental movement skills

\begin{tabular}{|l|l|}
\hline \multicolumn{2}{|c|}{ PHYSICAL EDUCATION LESSON PLAN } \\
\hline Subject & Physical Education and Sport \\
\hline Grade & 5 \\
\hline Duration & $40+40 \mathrm{dk}$. \\
\hline Learning Domain & 5.1. Motor Competence Learning Domain \\
\hline Sub-Domain & 5.1.1. Motor Skills Sub-Domain \\
\hline Learning Outcomes & $\begin{array}{l}\text { PE.5.1.1.2. Performs balance movements by showing awareness of body } \\
\text { and space. } \\
\text { PE.5.1.1.4. Displays combined movement skills in various games and } \\
\text { activities. }\end{array}$ \\
\hline Instruction Methods & Inquiry-Based Instructional Model \\
\hline $\begin{array}{l}\text { Education Technologies, } \\
\text { Materials and Equipment Used }\end{array}$ & CD, Tambourine or Goblet Drum, Whistle \\
\hline Lesson Location & Schoolyard, Sports Hall \\
\hline Security Measures & $\begin{array}{l}\text { Prior to the lesson, the activity area is scrutinised and delimited. } \\
\text { The lesson area is cleared of objects or anything unrelated to the activity. }\end{array}$ \\
\hline
\end{tabular}




\begin{tabular}{|c|c|}
\hline \multicolumn{2}{|r|}{ TEACHING AND LEARNING PROCESS } \\
\hline $\begin{array}{l}\text { Introduction } \\
\text { - Drawing attention of students } \\
\text { - Acquainting students with } \\
\text { objective }\end{array}$ & $\begin{array}{l}\text { The teacher takes attendance and greetings are made. The students form a U } \\
\text { shape. The teacher acquaints the students with the topic of lesson/ The } \\
\text { lesson has two topics. } \\
\text { 1. "What are locomotor skills?" } \\
\text { 2. "Which locomotor skills do you know?" } \\
\text { 3. "Can you show me walking and running movements?" } \\
\text { After waiting for } 10 \text { seconds, the teacher calls the running students to his } \\
\text { side. He/she says, "The movements you made are correct but there are } \\
\text { some deficiencies in your running style, and today we are going to correct } \\
\text { those." }\end{array}$ \\
\hline $\begin{array}{l}\text { Activity } 1 \\
\text { (Teacher asks questions while } \\
\text { student performs walking } \\
\text { technique) }\end{array}$ & $\begin{array}{l}\text { Elements of Walking: Using one student as a model, the teacher explains } \\
\text { walking technique by demonstrating it to the other students. }\end{array}$ \\
\hline Question: & $\begin{array}{l}\text { "While you are walking, look at your friend's feet. How does s/he move? } \\
\text { Answer: ........ }\end{array}$ \\
\hline Question: & $\begin{array}{l}\text { "While you are walking, look at your friend's body. What kind of stance } \\
\text { does s/he have? How does s/he move? Answer: ........ }\end{array}$ \\
\hline Question: & $\begin{array}{l}\text { "While you are walking, look at your friend's arms. How does s/he move? } \\
\text { Answer: ........ }\end{array}$ \\
\hline Question: & $\begin{array}{l}\text { "While you are walking, can you hear the rhythm of our footsteps? } \\
\text { Answer: ......... }\end{array}$ \\
\hline $\begin{array}{l}\text { (Teacher asks questions while } \\
\text { student performs running } \\
\text { technique) }\end{array}$ & $\begin{array}{l}\text { Elements of Running: Using one student as a model, the teacher explains } \\
\text { running technique by demonstrating it to the other students. }\end{array}$ \\
\hline Question: & $\begin{array}{l}\text { "While you are running, look at your friend's feet. How does s/he move?" } \\
\text { Answer: ......... }\end{array}$ \\
\hline Question: & $\begin{array}{l}\text { "While you are running, look at your friend's body. What kind of stance } \\
\text { does s/he have? How does s/he move?" Answer: ......... }\end{array}$ \\
\hline Question: & $\begin{array}{l}\text { "While you are running, look at your friend's arms. How does s/he move?" } \\
\text { Answer: ......... }\end{array}$ \\
\hline Question: & $\begin{array}{l}\text { "While you are running, can you hear the rhythm of our footsteps?" } \\
\text { Answer: ......... }\end{array}$ \\
\hline Activity 2 & $\begin{array}{l}\text { Running in the Free Area: } \\
\text { While the teacher creates a rhythm in the background from a CD or with a } \\
\text { goblet drum, he/she asks the students to run at different levels in the free } \\
\text { area. }\end{array}$ \\
\hline
\end{tabular}




\begin{tabular}{|c|c|}
\hline Question: & "Who will describe running in the free area to me?" Answer: ......... \\
\hline Question: & $\begin{array}{l}\text { "While you are running in the free area, why do you have to watch your } \\
\text { other friends as well?" Answer: ........ }\end{array}$ \\
\hline \multirow{2}{*}{ Question: } & While the students are running: \\
\hline & "Are you running fast?" Answer: ......... \\
\hline Question: & $\begin{array}{l}\text { "When the rhythm of the music changes, how does your running speed } \\
\text { change?" Answer: ......... }\end{array}$ \\
\hline & When the students stop: \\
\hline Question: & $\begin{array}{l}\text { "At which level did you perform better running movements?" } \\
\text { Answer: ........ }\end{array}$ \\
\hline Question: & "At which level did you have the most difficulty?" Answer: ......... \\
\hline Activity 3 & $\begin{array}{l}\text { While the teacher creates a rhythm in the background from a CD or with a } \\
\text { goblet drum, he/she tells the students to run in the free area and to change } \\
\text { direction at short intervals while running. }\end{array}$ \\
\hline Question: & $\begin{array}{l}\text { Before running: } \\
\text { "How many running directions are there?" Answer: (Forwards, backwards, } \\
\text { etc.) }\end{array}$ \\
\hline Question: & $\begin{array}{l}\text { "Which running direction do you think is the most difficult?" } \\
\text { Answer: ........ }\end{array}$ \\
\hline Question: & $\begin{array}{l}\text { "Why could this direction (the direction stated by the student) be more } \\
\text { difficult?" Answer: ......... }\end{array}$ \\
\hline Question: & $\begin{array}{l}\text { After running: } \\
\text { "Is it possible to run backwards?" Answer: ........ }\end{array}$ \\
\hline Question: & "Which running direction do you think is the easiest?" Answer: ......... \\
\hline Evaluation of the Lesson & $\begin{array}{l}\text { The teacher gives a summary of the lesson: "In our lesson today, we have } \\
\text { tried to learn running technique and rhythm, and how running can be in } \\
\text { different directions and levels. We have given examples with movements of } \\
\text { how a correct running technique should be while running and have tried to } \\
\text { put these examples into practice. When coming to our next lesson next } \\
\text { week, I would like you to come by investigating what kind of exercises and } \\
\text { movements can be done with the running tempo we have learnt today." The } \\
\text { lesson is ended by collecting the lesson materials. }\end{array}$ \\
\hline
\end{tabular}

\subsubsection{Implementation Schools}

The implementation was made at five different schools located in socio-culturally similar neighbourhoods in the Şehzadeler district of Manisa. While the schools were being specified, care was taken to ensure that as far as possible, they had similar equipment in terms of area 
and materials necessary for the subject of physical education.

\subsection{Research Model}

A quantitative research technique was used in the study. The research was carried out in a quasi-experimental post-test design with control group, which is a static group comparison design. Since "ready-made" groups are used in this design, it can also be defined as a single-factor design in which there is no random assignment. The groups' performance tasks are measured only after the implementation, and a significant difference in skills test mean scores found in favour of the experimental group indicates that the performance tasks have a significant effect, although it cannot be said that this argument is very powerful (Büyüköztürk, Kılıç Çakmak, Akgün, Karadeniz, \& Demirel, 2012; Karasar, 2017). According to Büyüköztürk (2014), the combination of the experimental variable with a pre-experimental measurement can result in a different effect from a change depending only on the experimental variable. As a result of this combination, the application of the same test twice with the same subjects at certain intervals can cause an individual to become familiar with the form and content of the test during the pre-test implementation. This situation may have an effect on post-test scores (Büyüköztürk, 2014). In most experiments, implementation of a pre-test is either impossible or is not required. In the quasi-experimental post-test design with experimental-control group, however, the negative effects of a pre-experimental measurement on internal and external validity can be prevented (Karasar, 2017).

Within the scope of the study, the reason for choosing this design was the possibility that the reliability of the study might be negatively affected as a result of the fact that during a pre-test, students may become familiar with the skills transferred in the lesson content and/or that learning may occur (Büyüköztürk, 2014).

\subsection{Data Analysis}

The frequencies, arithmetic means and standard deviations of the data were determined, and to test the effectiveness of the quasi-experimental process in the post-test design with control group, t-test was used. Whether or not the parametric tests of the data satisfied the preconditions were decided by examining the skewness and kurtosis values and equality of variance test results for each variable (Büyüköztürk, 2014). Table 2 shows the means, standard deviations, and skewness and kurtosis values related to the post-test scores of both groups for perceived motor competence. Type 1 error was set at $5 \%$. 


\section{Macrothink}

Table 2. Means, standard deviations, and skewness and kurtosis values related to post-test scores of experimental and control groups for perceived motor competence

\begin{tabular}{|c|c|c|c|c|c|c|c|c|}
\hline Group & Perceived Motor Competence & n & $\bar{X}$ & sd & Skewness & Kurtosis & Min. & Max. \\
\hline \multirow{2}{*}{ 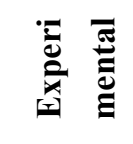 } & Locomotor skills & 134 & 3.18 & .042 & -.120 & -.842 & 2.08 & 4.00 \\
\hline & Object control skills & 134 & 3.05 & .041 & -.305 & -.167 & 1.58 & 4.00 \\
\hline \multirow{2}{*}{ 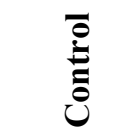 } & Locomotor skills & 126 & 2.91 & .047 & -.702 & .437 & 1.25 & 3.92 \\
\hline & Object control skills & 126 & 2.83 & .047 & -.506 & -.267 & 1.50 & 3.92 \\
\hline
\end{tabular}

With regard to the post-test scores of the experimental and control groups for perceived motor competence, as well as the central and distribution criteria, the skewness and kurtosis values can be seen. Accordingly, the skewness and kurtosis values are within the $-1,+1$ range, and fulfil the conditions of normal distribution.

\section{Findings}

Table 3. Values for experimental and control groups in sub-dimensions of perceived motor competence scale

\begin{tabular}{|l|l|l|l|l|l|l|l|l|}
\hline \multirow{2}{*}{ Perceived Motor Competence } & \multicolumn{3}{|c|}{ EXPERIMENTAL $(\mathbf{n}=\mathbf{1 3 4})$} & \multicolumn{3}{c|}{ CONTROL (n= 126) } \\
\cline { 2 - 10 } & Min. & Max. & $\bar{X}$ & $\mathbf{s d}$ & Min. & Max. & $\bar{X}$ & sd \\
\hline Locomotor Skills & $\mathbf{2 . 0 8}$ & $\mathbf{4 . 0 0}$ & $\mathbf{3 . 1 8}$ & $\mathbf{. 4 9 0}$ & $\mathbf{1 . 2 5}$ & $\mathbf{3 . 9 2}$ & $\mathbf{2 . 9 1}$ & $\mathbf{. 5 3 8}$ \\
\hline Running & 1.33 & 4.00 & 3.24 & .651 & 1.33 & 4.00 & 3.08 & .633 \\
\hline Jumping & 1.33 & 4.00 & 3.05 & .633 & 1.00 & 4.00 & 2.75 & .708 \\
\hline Hopping & 1.67 & 4.00 & 3.27 & .505 & 1.00 & 4.00 & 2.96 & .671 \\
\hline Leaping & 1.67 & 4.00 & 3.17 & .605 & 1.00 & 4.00 & 2.83 & .696 \\
\hline Object Control Skills & $\mathbf{1 . 5 8}$ & $\mathbf{4 . 0 0}$ & $\mathbf{3 . 0 5}$ & $\mathbf{. 4 8 3}$ & $\mathbf{1 . 5 0}$ & $\mathbf{3 . 9 2}$ & $\mathbf{2 . 8 3}$ & $\mathbf{. 5 3 7}$ \\
\hline Throwing & 1.33 & 4.00 & 3.14 & .646 & 1.67 & 4.00 & 2.93 & .634 \\
\hline Catching & 1.00 & 4.00 & 2.98 & .635 & 1.00 & 4.00 & 2.78 & .663 \\
\hline Bouncing & 1.00 & 4.00 & 2.97 & .701 & 1.00 & 4.00 & 2.68 & .814 \\
\hline Kicking & 1.33 & 4.00 & 3.10 & .689 & 1.00 & 4.00 & 2.92 & .758 \\
\hline
\end{tabular}


Table 4. Comparison of post-test scores obtained by students in experimental and control groups in sub-dimensions of perceived motor competence scale

\begin{tabular}{|c|c|c|c|c|c|c|c|}
\hline Perceived Motor Competence & Group & $\mathbf{n}$ & $\bar{X}$ & sd & df & $\mathbf{t}$ & $\mathbf{p}$ \\
\hline \multirow{2}{*}{ Locomotor Skills } & Experimental & 134 & 3.18 & .490 & \multirow{2}{*}{258} & \multirow{2}{*}{4.351} & \multirow{2}{*}{$.001 * *$} \\
\hline & Control & 126 & 2.91 & .538 & & & \\
\hline \multirow{2}{*}{ Running } & Experimental & 134 & 3.24 & .651 & \multirow{2}{*}{258} & \multirow{2}{*}{2.057} & \multirow{2}{*}{$.041 *$} \\
\hline & Control & 126 & 3.08 & .633 & & & \\
\hline \multirow{2}{*}{ Jumping } & Experimental & 134 & 3.05 & .633 & \multirow{2}{*}{258} & \multirow{2}{*}{3.548} & \multirow{2}{*}{$.001 * *$} \\
\hline & Control & 126 & 2.75 & .708 & & & \\
\hline \multirow{2}{*}{ Hopping } & Experimental & 134 & 3.27 & .505 & \multirow{2}{*}{258} & \multirow{2}{*}{4.232} & \multirow{2}{*}{$.001 * *$} \\
\hline & Control & 126 & 2.96 & .671 & & & \\
\hline \multirow{2}{*}{ Leaping } & Experimental & 134 & 3.17 & .605 & \multirow{2}{*}{258} & \multirow{2}{*}{4.213} & \multirow{2}{*}{$.001 * *$} \\
\hline & Control & 126 & 2.83 & .696 & & & \\
\hline \multirow{2}{*}{ Object Control Skills } & Experimental & 134 & 3.05 & .483 & \multirow{2}{*}{258} & \multirow{2}{*}{3.414} & \multirow{2}{*}{$.001 * *$} \\
\hline & Control & 126 & 2.83 & .537 & & & \\
\hline \multirow{2}{*}{ Throwing } & Experimental & 134 & 3.14 & .646 & \multirow{2}{*}{258} & \multirow{2}{*}{2.612} & \multirow{2}{*}{$.010^{*}$} \\
\hline & Control & 126 & 2.93 & .634 & & & \\
\hline \multirow{2}{*}{ Catching } & Experimental & 134 & 2.98 & .635 & \multirow{2}{*}{258} & \multirow{2}{*}{2.473} & \multirow{2}{*}{$.014 *$} \\
\hline & Control & 126 & 2.78 & .663 & & & \\
\hline \multirow{2}{*}{ Bouncing } & Experimental & 134 & 2.97 & .701 & \multirow{2}{*}{258} & \multirow{2}{*}{3.001} & \\
\hline & Control & 126 & 2.68 & .814 & & & $.003 *$ \\
\hline & Experimental & 134 & 3.10 & .689 & & & \\
\hline Kicking & Control & 126 & 2.92 & .758 & 258 & 1.960 & .051 \\
\hline
\end{tabular}

Note. $* * \mathrm{p}<.01 ; * \mathrm{p}<.05$.

As a result of the independent groups t-test performed to determine whether or not the inquiry-based instructional model in the teaching of fundamental movement skills to fifth-grade students had an effect on their perceived motor competence, significant differences were found. A significant difference was obtained in scores for locomotor skills in favour of the experimental group $\left(\mathrm{t}_{(258)}=4.351 ; \mathrm{p}=0.001\right)$. Moreover, differences in favour of the experimental group were obtained in scores for running, jumping, hopping and leaping sub-skills $(\mathrm{p}<.05)$. A significant difference was also obtained in scores for object control 
skills in favour of the experimental group $\left(\mathrm{t}_{(258)}=3.414 ; \mathrm{p}=0.001\right)$. While there were significant differences in the throwing, catching and bouncing sub-skills $(\mathrm{p}<.05)$, the difference in the kicking sub-skill was not statistically significant $(\mathrm{p}>.05)$.

Table 5. Comparison of post-test scores obtained by female students in experimental and control groups in sub-dimensions of perceived motor competence scale

\begin{tabular}{|c|c|c|c|c|c|c|c|}
\hline Perceived Motor Competence & Group & $\mathbf{n}$ & $\bar{X}$ & sd & df & $\mathbf{t}$ & $\mathbf{p}$ \\
\hline \multirow{2}{*}{ Locomotor Skills } & Experimental & 73 & 3.16 & .473 & \multirow{2}{*}{138} & \multirow{2}{*}{2.474} & \multirow{2}{*}{$.015^{*}$} \\
\hline & Control & 67 & 2.94 & .556 & & & \\
\hline \multirow{2}{*}{ Running } & Experimental & 73 & 3.23 & .632 & \multirow{2}{*}{138} & \multirow{2}{*}{.963} & \multirow{2}{*}{.337} \\
\hline & Control & 67 & 3.12 & .638 & & & \\
\hline \multirow{2}{*}{ Jumping } & Experimental & 73 & 3.04 & .616 & \multirow{2}{*}{138} & \multirow{2}{*}{2.189} & \multirow{2}{*}{$.030 *$} \\
\hline & Control & 67 & 2.79 & .731 & & & \\
\hline \multirow{2}{*}{ Hopping } & Experimental & 73 & 3.28 & .510 & \multirow{2}{*}{138} & \multirow{2}{*}{2.570} & \multirow{2}{*}{$.011 *$} \\
\hline & Control & 67 & 3.03 & .629 & & & \\
\hline \multirow{2}{*}{ Leaping } & Experimental & 73 & 3.09 & .601 & \multirow{2}{*}{138} & \multirow{2}{*}{2.324} & \multirow{2}{*}{$.022 *$} \\
\hline & Control & 67 & 2.83 & .723 & & & \\
\hline \multirow{2}{*}{ Object Control Skills } & Experimental & 73 & 2.93 & .468 & \multirow{2}{*}{138} & \multirow{2}{*}{2.112} & \multirow{2}{*}{$.037^{*}$} \\
\hline & Control & 67 & 2.75 & .513 & & & \\
\hline \multirow{2}{*}{ Throwing } & Experimental & 73 & 2.94 & .662 & \multirow{2}{*}{138} & \multirow{2}{*}{2.112} & \multirow{2}{*}{.342} \\
\hline & Control & 67 & 2.83 & .633 & & & \\
\hline \multirow{2}{*}{ Catching } & Experimental & 73 & 2.94 & .586 & \multirow{2}{*}{138} & \multirow{2}{*}{.954} & \multirow{2}{*}{.077} \\
\hline & Control & 67 & 2.75 & .637 & & & \\
\hline \multirow{2}{*}{ Bouncing } & Experimental & 73 & 3.00 & .707 & \multirow{2}{*}{138} & \multirow{2}{*}{1.784} & \\
\hline & Control & 67 & 2.77 & .772 & & & .065 \\
\hline & Experimental & 73 & 2.83 & .657 & (2) & 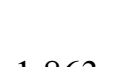 & \\
\hline КСКПП & Control & 67 & 2.65 & .763 & 158 & 1.803 & .159 \\
\hline
\end{tabular}

Note. ${ }^{*} \mathrm{p}<.05$.

As a result of the independent groups t-test performed to determine whether or not the inquiry-based instructional model in the teaching of fundamental movement skills to 
fifth-grade female students had an effect on their perceived motor competence, significant differences were found. A significant difference was obtained in scores for locomotor skills in favour of girls in the experimental group $\left(\mathrm{t}_{(138)}=2.474 ; \mathrm{p}=0.015\right)$. Furthermore, differences in favour of the experimental group were obtained in scores for jumping, hopping and leaping sub-skills $(\mathrm{p}<.05)$, though no difference was found for the running sub-skill $(\mathrm{p}>.05)$. A significant difference was also obtained in scores for object control skills in favour of girls in the experimental group $\left(\mathrm{t}_{(258)}=2.112 ; \mathrm{p}=0.037\right)$. Scores for throwing, catching, bouncing and kicking sub-skills were not found to be statistically significant $(\mathrm{p}>.05)$.

Table 6. Comparison of post-test scores obtained by male students in experimental and control groups in sub-dimensions of perceived motor competence scale

\begin{tabular}{|c|c|c|c|c|c|c|c|}
\hline Perceived Motor Competence & Group & $\mathbf{n}$ & $\bar{X}$ & sd & df & $\mathbf{t}$ & $\mathbf{P}$ \\
\hline \multirow{2}{*}{ Locomotor Skills } & Experimental & 61 & 3.21 & .512 & \multirow{2}{*}{118} & \multirow{2}{*}{3.715} & \multirow{2}{*}{$.001 * *$} \\
\hline & Control & 59 & 2.86 & .519 & & & \\
\hline \multirow{2}{*}{ Running } & Experimental & 61 & 3.26 & .677 & \multirow{2}{*}{118} & \multirow{2}{*}{1.957} & \multirow{2}{*}{.053} \\
\hline & Control & 59 & 3.03 & .630 & & & \\
\hline \multirow{2}{*}{ Jumping } & Experimental & 61 & 3.06 & .657 & \multirow{2}{*}{118} & \multirow{2}{*}{2.837} & \multirow{2}{*}{$.005^{* *}$} \\
\hline & Control & 59 & 2.71 & .685 & & & \\
\hline \multirow{2}{*}{ Hopping } & Experimental & 61 & 3.25 & .504 & \multirow{2}{*}{118} & \multirow{2}{*}{3.397} & \multirow{2}{*}{$.001^{* *}$} \\
\hline & Control & 59 & 2.87 & .711 & & & \\
\hline \multirow{2}{*}{ Leaping } & Experimental & 61 & 3.28 & .598 & \multirow{2}{*}{118} & \multirow{2}{*}{3.766} & \multirow{2}{*}{$.001 * *$} \\
\hline & Control & 59 & 2.84 & .670 & & & \\
\hline \multirow{2}{*}{ Object Control Skills } & Experimental & 61 & 3.19 & .466 & \multirow{2}{*}{118} & \multirow{2}{*}{2.893} & \multirow{2}{*}{$.005^{* *}$} \\
\hline & Control & 59 & 2.92 & .554 & & & \\
\hline \multirow{2}{*}{ Throwing } & Experimental & 61 & 3.38 & .538 & \multirow{2}{*}{118} & \multirow{2}{*}{2.893} & \multirow{2}{*}{$.005 * *$} \\
\hline & Control & 59 & 3.05 & .621 & & & \\
\hline \multirow{2}{*}{ Catching } & Experimental & 61 & 3.04 & .689 & \multirow{2}{*}{118} & \multirow{2}{*}{3.180} & \multirow{2}{*}{$.002 * *$} \\
\hline & Control & 59 & 2.82 & .695 & & & \\
\hline \multirow{2}{*}{ Bouncing } & Experimental & 61 & 2.92 & .697 & \multirow{2}{*}{118} & \multirow{2}{*}{1.730} & \\
\hline & Control & 59 & 2.58 & .853 & & & .000 \\
\hline & Experimental & 61 & 3.42 & .586 & & & \\
\hline KICKIng & Control & 59 & 3.23 & .632 & 118 & 2.503 & $.020^{\circ}$ \\
\hline
\end{tabular}

Note. ${ }^{*} \mathrm{p}>.05 ; * * \mathrm{p}<.01$. 
As a result of the independent groups t-test performed to determine whether or not the inquiry-based instructional model in the teaching of fundamental movement skills to fifth-grade male students had an effect on their perceived motor competence, significant differences were found. A significant difference was obtained in scores for locomotor skills in favour of boys in the experimental group $\left(\mathrm{t}_{(118)}=3.715 ; \mathrm{p}=0.001\right)$. Moreover, differences in favour of the experimental group were obtained in scores for jumping, hopping and leaping sub-skills $(\mathrm{p}<.05)$, though no difference was found for the running sub-skill $(\mathrm{p}>.05)$. A significant difference was also obtained in scores for object control skills in favour of boys in the experimental group $\left(\mathrm{t}_{(118)}=2.893 ; \mathrm{p}=0.005\right)$. While there were significant differences in the throwing, catching and kicking sub-skills $(\mathrm{p}<.05)$, the difference in the bouncing sub-skill was not statistically significant $(\mathrm{p}>.05)$.

Table 7. Comparison of post-test scores obtained by students in experimental group in sub-dimensions of perceived motor competence scale according to gender variable

\begin{tabular}{|c|c|c|c|c|c|c|c|}
\hline Perceived Motor Competence & Gender & $\mathbf{n}$ & $\bar{X}$ & sd & df & $\mathbf{t}$ & $\mathbf{p}$ \\
\hline \multirow{2}{*}{ Locomotor Skills } & Female & 73 & 3.16 & .473 & \multirow{2}{*}{132} & \multirow{2}{*}{-.620} & \multirow{2}{*}{.537} \\
\hline & Male & 61 & 3.21 & .512 & & & \\
\hline \multirow{2}{*}{ Running } & Female & 73 & 3.23 & .632 & \multirow{2}{*}{132} & \multirow{2}{*}{-.308} & \multirow{2}{*}{.759} \\
\hline & Male & 61 & 3.26 & .677 & & & \\
\hline \multirow{2}{*}{ Jumping } & Female & 73 & 3.04 & .616 & \multirow{2}{*}{132} & \multirow{2}{*}{-.181} & \multirow{2}{*}{.857} \\
\hline & Male & 61 & 3.06 & .657 & & & \\
\hline \multirow{2}{*}{ Hopping } & Female & 73 & 3.28 & .510 & \multirow{2}{*}{132} & \multirow{2}{*}{.412} & \multirow{2}{*}{.681} \\
\hline & Male & 61 & 3.25 & .504 & & & \\
\hline \multirow{2}{*}{ Leaping } & Female & 73 & 3.09 & .601 & \multirow{2}{*}{132} & \multirow{2}{*}{-1.852} & \multirow{2}{*}{.066} \\
\hline & Male & 61 & 3.28 & .598 & & & \\
\hline \multirow{2}{*}{ Object Control Skills } & Female & 73 & 2.93 & .468 & \multirow{2}{*}{132} & \multirow{2}{*}{-3.236} & \multirow{2}{*}{$.002 * *$} \\
\hline & Male & 61 & 3.19 & .466 & & & \\
\hline \multirow{2}{*}{ Throwing } & Female & 73 & 2.94 & .662 & \multirow{2}{*}{132} & \multirow{2}{*}{-4.232} & \multirow{2}{*}{$.001 * *$} \\
\hline & Male & 61 & 3.38 & .538 & & & \\
\hline \multirow{2}{*}{ Catching } & Female & 73 & 2.94 & .586 & \multirow{2}{*}{132} & \multirow{2}{*}{-.935} & \multirow{2}{*}{.351} \\
\hline & Male & 61 & 3.04 & .689 & & & \\
\hline \multirow{2}{*}{ Bouncing } & Female & 73 & 3.00 & .707 & \multirow{2}{*}{132} & \multirow{2}{*}{.702} & 104 \\
\hline & Male & 61 & 2.92 & .697 & & & .404 \\
\hline$V_{0}$ & Female & 73 & 2.83 & .657 & & & \\
\hline КСКПт & Male & 61 & 3.42 & .586 & 21כ & .000 & .001 \\
\hline
\end{tabular}

Note. $* * \mathrm{p}<.01, * \mathrm{p}<.05$. 
As a result of the independent groups t-test performed to determine whether or not the inquiry-based instructional model in the teaching of fundamental movement skills to fifth-grade students in the experimental group had an effect on their perceived motor competence according to gender, significant differences were found in object control skills. A significant difference was obtained in scores for object control skills in favour of boys $\left(\mathrm{t}_{(132)}=\right.$ 3.236; $\mathrm{p}=0.002$ ). While significant differences in throwing and kicking sub-skills were also found in favour of boys $(\mathrm{p}<.01)$, differences in catching and bouncing sub-skills were not statistically significant $(\mathrm{p}>.05)$.

Table 8. Comparison of post-test scores obtained by students in control group in sub-dimensions of perceived motor competence scale according to gender variable

\begin{tabular}{|c|c|c|c|c|c|c|c|}
\hline Perceived Motor Competence & Gender & $\mathbf{n}$ & $\bar{X}$ & sd & df & $\mathbf{t}$ & $\mathbf{p}$ \\
\hline \multirow{2}{*}{ Locomotor Skills } & Female & 67 & 2.94 & .556 & \multirow{2}{*}{124} & \multirow{2}{*}{.849} & \multirow{2}{*}{.397} \\
\hline & Male & 59 & 2.86 & .519 & & & \\
\hline \multirow{2}{*}{ Running } & Female & 67 & 3.12 & .638 & \multirow{2}{*}{124} & \multirow{2}{*}{.843} & \multirow{2}{*}{.401} \\
\hline & Male & 59 & 3.03 & .630 & & & \\
\hline \multirow{2}{*}{ Jumping } & Female & 67 & 2.79 & .731 & \multirow{2}{*}{124} & \multirow{2}{*}{.619} & \multirow{2}{*}{.537} \\
\hline & Male & 59 & 2.71 & .685 & & & \\
\hline \multirow{2}{*}{ Hopping } & Female & 67 & 3.03 & .629 & \multirow{2}{*}{124} & \multirow{2}{*}{1.422} & \multirow{2}{*}{.158} \\
\hline & Male & 59 & 2.87 & .711 & & & \\
\hline \multirow{2}{*}{ Leaping } & Female & 67 & 2.83 & .723 & \multirow{2}{*}{124} & \multirow{2}{*}{-.133} & \multirow{2}{*}{.894} \\
\hline & Male & 59 & 2.84 & .670 & & & \\
\hline \multirow{2}{*}{ Object Control Skills } & Female & 67 & 2.75 & .513 & \multirow{2}{*}{124} & \multirow{2}{*}{-1.760} & \multirow{2}{*}{.081} \\
\hline & Male & 59 & 2.92 & .554 & & & \\
\hline \multirow{2}{*}{ Throwing } & Female & 67 & 2.83 & .633 & \multirow{2}{*}{124} & \multirow{2}{*}{-1.917} & \multirow{2}{*}{.057} \\
\hline & Male & 59 & 3.05 & .621 & & & \\
\hline \multirow{2}{*}{ Catching } & Female & 67 & 2.75 & .637 & \multirow{2}{*}{124} & \multirow{2}{*}{-.578} & \multirow{2}{*}{.564} \\
\hline & Male & 59 & 2.82 & .695 & & & \\
\hline \multirow{2}{*}{ Bouncing } & Female & 67 & 2.77 & .772 & \multirow{2}{*}{124} & \multirow{2}{*}{1.301} & \\
\hline & Male & 59 & 2.58 & .853 & & & .190 \\
\hline & Female & 67 & 2.65 & .763 & & & \\
\hline какm5 & Male & 59 & 3.23 & .632 & 12 & T. & .001 \\
\hline
\end{tabular}

Note. $* * \mathrm{p}<.01$. 
As a result of the independent groups t-test performed to determine whether or not the direct instructional model in the teaching of fundamental movement skills to fifth-grade students in the control group had an effect on their perceived motor competence according to gender, significant differences were found in the kicking sub-skill. A significant difference in scores for the kicking sub-skill was found in favour of boys $\left(\mathrm{t}_{(124)}=4.569 ; \mathrm{p}=0.001\right)$.

\section{Discussion}

This study examined the effects of lesson content aimed at fostering basic motor skills taught with the inquiry-based instructional model, which is one of the models used in secondary school physical education lessons, on students' perceived motor competence. Moreover, comparisons based on gender were made and an attempt was made to reveal differences. According to the findings obtained, significant differences were found in students' levels of perceived motor competence for lesson content taught with the inquiry-based instructional model, according to group (experimental/control) and gender factors.

When studies in the literature are examined, the use of direct instruction in the control group in experimental design studies is a frequently encountered situation. Direct instruction in physical education lessons, or as it is commonly known, the command style, is evaluated as a very effective method for realising physical and cognitive learning. This teaching style is used essentially for achieving goals such as uniformity, simultaneous performance, conformity with a model, promoting the team spirit mentality of the group, and using time productively, by providing the opportunity for a greater number of repeated movements under the control of the teacher (Mosston \& Ashworth, 2008). However, student-centred styles (guided discovery, problem-solving, student design, student initiation, and self-teaching style learning) and models (the sport education model, the tactical games model, the inquiry-based instructional model, and the personal and social responsibility model), which are used less frequently than direct instruction, also enable the student to be significantly influenced in a cognitive sense (Mirzeoğlu, 2017). Among these models, the inquiry-based instructional model appears before us as one of the least used models due to difficulties in its implementation and the broad scope that it has. In this context, it is seen that the number of studies conducted with the inquiry-based instructional model in the field of physical education and sport is very low. One of these was carried out by Uzunosmanoglu, Gursel, and Arslan (2012) in an experimental design with control group. As a result of their study, it was determined that at the end of the health-related fitness programme carried out with the inquiry-based instructional model, scores of the experimental group for flexibility, sit-up, pull-up and sit-up run skills were higher than those of the control group. In another study conducted in an experimental design with 10th-grade students, instruction in tiger spring and cartwheel skills in gymnastics skills was carried out with the inquiry-based instructional model in the experimental group and command-based instruction in the control group, and following measurement of psychomotor skills, it was concluded that both methods of instruction were effective (Firmansyah, 2016). In a study in which the effect of the inquiry-based instructional model on the teaching of soccer skills was investigated, it was found that this instructional model was more effective than the direct instructional model (Hendrayana \& Widyawan, 2016). In another study carried out on male students studying in 
the physical education department at a university, implementation of network information technology learning in basketball was more effective with the inquiry-based instructional model than with other methods (Aimin, Jianjun, Ganchen, Yuanping, \& Shaoyong, 2015). It was seen that during the preservice physical education teachers' learning, receiving instruction related to the inquiry-based instructional model resulted in their being more effective and productive in their teaching practices. Moreover, in terms of teaching skills, this model enables retention of knowledge that can be transferred to working life (Østergaard, 2019). In a study made by Samaha (2019), however, the inquiry-based instructional model and interactive instruction for fostering the perception of muscle function in first-year university students in a physical education and sport department were applied to different groups in a single session, but in the knowledge dimension, no difference between the groups was obtained.

According to Purichia (2015), inquiry-based learning lies at the basis of the effect created by the RBIM, and when students encounter a problem or question, the learn in a deep and authentic way, since the inquiry-based instructional model encourages students to think, take action, and to use all of both their cognitive and physical competencies. Therefore, it is a very motivating and interesting model for students (Østergaard, 2016). It stimulates students' curiosity and participation and encourages them to take action. This situation enables students to make more gains especially from physical education, and in terms of importance for their lives, leads them to develop a deeper understanding (Lynott III \& Bittner, 2019). It is stated that with these characteristics, the inquiry-based method of instruction can effectively complement and improve traditional instruction (Aimin et al., 2015). In contrast with traditional methods, it includes inductive reasoning and places the student more at the centre. It gives more importance to students' taking responsibility for their own learning (Duncan \& Lyons, 2008). Dostál (2015) states that when inquiry-based instruction is used in the general education curriculum, students who learn in this way think critically, make effective decisions, can demonstrate their ideas, are conscious of their responsibility for their own decisions, and can evaluate the consequences of their own actions. Gore, Griffiths, and Ladwig (2004) interpreted the combined use of inquiry-based learning and Moston's guided discovery models as mutually supportive and similar in physical education lessons. It is argued that these models support a productive pedagogical framework by means of activities guided by students, and that they provide the opportunity for students to establish relationships among experiences with the knowledge that they create during activities (Gore et al., 2004, cited in Usher, Edwards, \& Meyrick, 2015).

Studies conducted in different fields in an experimental design with the inquiry-based instructional model can also be found. For example, inquiry- or research-based instruction has been implemented in numerous studies conducted in the field of science, and significant results in favour of experimental groups have been achieved (Lord \& Orkwiszewski, 2006; Altunsoy, 2008; Parim, 2009; Tatar, 2006; Tatar \& Kuru, 2009; Panasan \& Nuangchalerm, 2010; Tretter \& Jones, 2003; Von Secker, 2002; Çalışkan, 2009). Similar findings were also made in a study carried out in the field of social sciences, and it was determined that critical thinking levels in students subjected to an inquiry-based learning approach were better 
developed that those of other students (Çalışkan, 2009).

When the abovementioned research studies are evaluated, it is seen that the use of the inquiry-based instructional model in both the field of physical education and sport and in other fields develops critical thinking more than traditional instructional practices, that it has a positive effect on student outcomes, that it provides more support for their cognitive skills in particular, and that their findings are in parallel with those of the present study.

In the experimental group in which the inquiry-based instructional model was implemented, both female and male students obtained higher scores in locomotor and object control skills than those included in the control group. Moreover, when participants in both groups were compared within themselves in terms of the gender factor, it was found that the object control skills of male students in the experimental group were at a better level than those of female students. In terms of the subdimensions, too, it was revealed that scores of males in the experimental group for throwing and kicking skills were higher than those of females. In the control group, however, it was seen that male students' scores were higher than those of females only in the kicking subdimension. Based on these findings, it can be said that male students were more affected by the experimental variable in the scope of the research. When studies related to the subject are examined, in a norm study conducted in Turkey, the motor skills of students in educational stage II (5th-8th grade) were assessed with the Dordel-Koch test, and it was seen that apart from flexibility requiring strength, agility and resilience, males had higher values than females in all skills. In the same study, in the side-jumping test (in which coordination, agility and maintaining strength of the leg muscles are a priority), however, it was revealed that girls in the 11-12 age group had higher values than boys, but that in the 13-14 age group, the exact opposite finding was made (Gözel Tepe, 2016). In a study made by Aydın (2009), it was also found that locomotor and object control skill scores of girls aged 10 were higher than those of boys. In a study carried out in Brazil by Spessato, Gabbard, Valentini, and Rudisill (2013), however, it was revealed that boys' object control and locomotor skill values were superior to those of girls. Considered from the viewpoint of this review of the studies, it is seen that this study conforms to studies in the literature, except that in both groups separately, there was a difference between genders in the "kicking" skill in favour of boys. This finding can be associated with the fact that ball games are very widespread as a street game in Turkey, since it can be observed that both girls and boys use this skill widely with balls and similar materials as soon as they begin to walk.

\section{Conclusion and Recommendations}

As a result of the study, it can be said that the inquiry-based instructional model was more effective for the development of the motor skills of "locomotor skills" and "object control skills" than the direct instructional model. Moreover, when evaluated in terms of gender, male students benefited more from the inquiry-based instructional model regarding "object control skills". Based on the results that were obtained, recommendations for practice and research are given below. 


\subsection{Recommendations for Practice}

It was seen that there is a need for developing awareness and skills related to model-based instructional practices with in-service training or additional courses for physical education teachers, especially those with many years of experience and those who have difficulty in keeping up with current educational issues. The inquiry-based instructional model should be used by physical education teachers in school for the purpose of techniques and especially of tactical training in branches of sport, in order to develop high-order thinking skills in students. In the literature, it is seen that physical education teachers generally use direct instructional methods. It is recommended that motivation-increasing policies that will steer teachers away from this approach are developed by the Ministry of National Education, and that these are supported and implemented by teacher training institutions.

\subsection{Recommendations for Future Research}

Discussion of the inquiry-based instructional model together with other models that differ from direct instruction in the teaching of fundamental movement skills will contribute to the literature. By combining models for the instruction of physical education and sport, educational experiments can be made in line with different course objectives.

\section{Acknowledgements}

The authors would like to thank the teachers who teach the fundamental movement skills with inquiry-based instructional model and to student who participated in this study.

\section{References}

Aimin, L., Jianjun, L., Ganchen, T., Yuanping, C., \& Shaoyong, W. (2015). Research on the inquiry teaching model of men's basketball teaching in college physical education based on network information technology. International Journal of Smart Home, 9(10), 169-178. https://doi.org/10.14257/ijsh.2015.9.10.19

Akpullukçu, S. (2011). Fen ve teknoloji dersinde araştırmaya dayalı öğrenme Ortamının ögrencilerin akademik başarı, hatırda tutma düzeyi ve tutumlarına etkisi (Unpublished Master's thesis, Dokuz Eylül University Institute of Educational Sciences, İzmir).

Alagül, Ö., \& Gürsel, F. (2019). Değişe(meye)n Öğretmenler: Beden Eğitimi Öğretmenlerinin Profesyonel Gelişimlerinde Pedagojik Yenilikleri Deneyimleme Süreçleri. Eğitim ve Bilim Dergisi, 44(197), 401-420. https://doi.org/10.15390/EB.2019.8016

Altunsoy, S. (2008). Ortaögretim Biyoloji Öğretiminde Araştırmaya Dayalı Öğrenme Yaklaşımının Öğrencilerin Bilimsel Süreç Becerilerine, Akademik Başarılarına ve Tutumlarına Etkisi (Master's thesis, Selçuk University, Institute of Science, Konya).

Asma, M., \& Soytürk, M. (2018). Farklı öğretim biçimleri ile gerçekleştirilen voleybol derslerinin öğrenme çıtıları açısından incelenmesi. Uluslararası Insan Bilimleri Dergisi, 15(2), 779-798. https://doi.org/10.14687/jhs.v15i2.5270 
Aydın, S. (2009). Kütahya ilinde salon sporlarında müsabakalara katılan ilkögretim I. kademe 10 yaş grubu ögrencilerinin TGMD-II testine göre motor gelişme düzeylerinin araştırılması (Master's thesis, Kütahya Dumlupınar University Institute of Social Sciences, Kütahya).

Bayhan, P. S., \& Artan, İ. (2009). Motor gelişim. In P. S. Bayhan \& İ. Artan (Eds.), Çocuk gelişimi ve eğitimi içinde (pp. 168-190). İstanbul: Morpa Kültür Yayınları.

Berigel, G. (2015). 04-06 Yaş grubu otizmli çocuklarda spor aktivitelerinin öz bakım, ince-kaba motor ve dil bilişsel gelişimine etkilerinin incelenmesi (Master's thesis, Haliç University Institute of Health Sciences, İstanbul).

Boz, M., \& Güngör Aytar, A. (2012). Büyük kas motor gelişim-2 (TGMD-2) testinin Türk çocuklarına uyarlama çalışması. Akdeniz Eğitim Araştırmaları Dergisi, 6(12), 17-24. https://doi.org/10.29329/mjer

Bulca, Y. (2017). Araştırmaya dayalı öğretme modeli. In A. D. Mirzeoğlu (Ed.), Model temelli beden eğitimi öğretimi içinde (pp. 185-208). Ankara: Spor Yayınevi ve Kitapevi.

Büyüköztürk, Ş. (2014). Deneysel desenler: Öntest-sontest kontrol grubu, desen ve veri analizi (4th ed.). Ankara. Pegem Akademi.

Büyüköztürk, Ş., Kılıç Çakmak, E., Akgün, Ö. E., Karadeniz, Ş., \& Demirel, F. (2012). Bilimsel araştırma yöntemleri (12th ed.). Ankara. Pegem Akademi

Casey, A., \& Dyson, B. (2009). The implementation of models-based practice in physical education through action research. European Physical Education Review, 15(2), 175-199. https://doi.org/10.1177/1356336X09345222

Casey, A., Goodyear, V. A., \& Dyson, B. (2015). Model fidelity and students' responses to an authenticated unit of cooperative learning. Journal of Teaching in Physical Education, 34(4), 642-660. https://doi.org/10.1123/jtpe.2013-0227

Çalışkan, H. (2009). Sosyal bilgiler öğretiminde araştırmaya dayalı öğrenme yaklaşımının eleştirel düşünme becerisine etkisi. Kastamonu Eğitim Dergisi, 17(1), 57-70. Retrieved from https://dergipark.org.tr/tr/pub/kefdergi/issue/49070/626123

Çayır, Ç. (2019). 7-8 yaşlarındaki çocukların katıldıkları farklı sporsal aktivitelerin motor gelişimlerine etkisi (Master's thesis,. Selcuk University Institute of Health Sciences, Konya).

Demirci, N., \& Toptaş Demirci, P. (2016). Özel öğrenme güçlüğü olan çocukların kaba ve ince motor becerilerinin değerlendirilmesi. Inönü Üniversitesi Beden Ĕgitimi ve Spor Bilimleri Dergisi, 3(1), 47-57. Retrieved from https://dergipark.org.tr/tr/pub/inubesyo/ issue $/ 28567 / 304807$

Dostal, J. (2015). Inquiry based learning in school and informal education (1st ed.). Palack'y University Olomouc Faculty of Education, Olomouc. https://doi.org/10.5507/pdf.15.244 45076 
Doydu, İ., Çelen, A., \& Çoknaz, H. (2013). The effect of the sports education model on the attitudes of students towards physical education and sports. e-International Journal of Educational Research, 4(2), 99-110. Retrieved from http://www.dergipark.org.tr/en/pub/ijer/ issue $/ 8022 / 105386$

Duman, G. (2019). Temel Motor Beceriler Kazandırma Eğitim Programının Analizi. Turkish Journal of Primary Education, 4(2), 112-120. Retrieved from https://dergipark.org.tr/tr/pub/ tujped/issue $/ 50537 / 666637$

Duncan, M. J., \& Lyons, M. (2008). Using enquiry based learning in sports and exercise sciences: A Case Study from Exercise Biomechanics. Practice and Evidence of Scholarship of Teaching and Learning in Higher Education, 3(1), 43-56.

Fansa, M. (2012). Araştırma dayalı öğrenme yönteminin ilköğretim 5. sinıf öğrencilerinin maddenin değişimi ve tanınması ünitesindeki akademik başarı, fen dersine karşı tutum ve bilimsel süreç becerilerine etkisinin incelenmesi (Master's thesis, Mustafa Kemal University Institute of Social Sciences, Hatay).

Filiz, B. (2019). Using personal and social responsibility model for gaining leadership behavior in students. European Journal of Educational Research, 8(1), 157-168. https://doi.org/10.12973/eu-jer.8.1.157

Firmansyah, H. (2016). Effect direct and indirect (1nquiry) instructions model in teaching gymnastics. Jurnal Publikasi Pendidikan, VI(3), 174-178. https://doi.org/10.26858/publikan. v6i3.2272

Gallahue, D. L., (1976). Motor Ddevelopment and Movement Experiences for Young Children. Indiana: Winley John Winley \& Sons, Inc.

Gözel Tepe, Z. (2016). Dordel-koch testin Türk çocuklar ve gençler üzerinde norm veri çalışması ve motorik becerilerin araştırllması (Doctoral thesis, Dumlupınar University Institute of Health Sciences, Kütahya).

Gül, Ö. (2012). Oyun ve hareket temelli büyük kas beceri eğitim programlarının 4-5 yaş çocukların büyük kas becerilerine etkisinin karşılaştırılması (Doctoral thesis, Selçuk University Institute of Social Sciences, Konya).

Gürker Tepe, M. (2018). Ankara Çankaya ilçesinde bir ilköğretim okulunda okuyan 9-10 yaş çocukların temel motorik özelliklerinin ölçülmesi (Master's thesis, Aksaray University Institute of Social Sciences, Aksaray).

Hendrayana, Y., \& Widyawan, D. (2016). The influence of a learning model with scientific approach on soccer skills. SOSIO HUMANIKA: Jurnal Pendidikan Sains Sosial dan Kemanusiaan, 9(2), 325-334. https://doi.org/10.2121/sosiohumanika.v9i2.735

Hürmeriç Altınsöz, I., \& Mülazımoğlu Ballı, Ö. (2017). İlköğretim öğrencilerine uygulanan motor beceri programlarının değerlendirilmesi. In Ö. Demirel \& S. Dinçer (Eds.), Küreselleşen Dünyada Eğitim Içinde (pp. 671-678). Ankara: Pegem Akademi. https://doi.org/10.14527/9786053188407.47 


\section{Macrothink}

Journal of Educational Issues

ISSN 2377-2263

2020, Vol. 6, No. 2

Karasar, N. (2017). Bilimsel Araştırma Yöntemi: Kavramlar Illkeler Teknikler (32nd ed.). Ankara: Nobel Akademik Yayıncılık.

Karatel, M. K. (2019). Denver II gelişimsel tarama testi sonucu anormal veya şüpheli olan 4-6 yaş grubu çocuklarda uygulanacak olan eğitim öncesi ve sonrası gelişim parametrelerinin ve motor performansin incelenmesi (Master's thesis, Hasan Kalyoncu University Institute of Health Sciences, Gaziantep).

Kılıç, Z., Uyanık Balat, G., \& Çağlak Sarı, S. (2017). CHAMPS motor beceriler protokolü'nün (CMPS) 4 ve 5 yaş çocuklarına yönelik Türkçe'ye uyarlama çalışması. Ĕgitim Kuram ve Uygulama Araştırmaları Dergisi, 3(3), 129-142. Retrieved from https://dergipark. org.tr/tr/pub/ekuad/issue/31101/355398

Kirk, D. (2013) Educational value and models-based practice in physical education, Educational Philosophy and Theory, 45(9), 973-986. https://doi.org/10.1080/00131857. 2013.785352

Köse, B. (2018). Bruininks-Oseretsky motor yeterlik testi 2 kısa formunun Türkçe uyarlaması ve özgül öğrenme güçlü̆̆̈̈ olan çocuklarda geçerlilik ve güvenilirliği (Master's thesis, Hacettepe University Institute of Health Sciences, Ankara).

Kula, G. Ş. (2009). Araştırmaya dayalı fen ögrenmenin öğrencilerin bilimsel süreç becerileri, başarıları, kavram ögrenmeleri ve tutumlarına etkisi (Master's thesis, Marmara University Institute of Educational Sciences, Istanbul).

Livonen, S., \& Saakslahti, A. K. (2014). Preschool children's fundemental motor skills: A review of significant determinants. Early Child Development and Care, 184(7), 1107-1126. https://doi.org/10.1080/03004430.2013.837897

Lord, T, Orkwiszewski T. (2006). Moving from didactic to inquiry-based instruction in a science laboratory. The American Biology Teacher, 68(6), 342-345. https://doi.org/10.2307/ 4452009

Lynott III Francis, J., \& Bittner Gina, L. (2019). Moving toward developing inquiry skills: Inquiry-based learning in physical education. Strategies, 32(2), 32-38. https://doi.org/ $10.1080 / 08924562.2018 .1560135$

MEB. (2018). Ortaokul (5-8. sinıflar) beden eğitimi ve spor dersi öğretim programı. 652 Sayılı Talim Terbiye Kurulu Kararı (No. 6, pp. 12-30). Ankara, Turkey. Retrieved from https://mufredat.meb.gov.tr

Mirzeoğlu, A. D. (2017). Model temelli beden eğitimi öğretimi. Ankara: Spor Yayınevi.

Mosston, M., \& Ashworth, S. (2008). Teaching physical education (1st ed.). Retrieved from https://spectrumofteachingstyles.org/index.php?id = 16

Mülazımoğlu Ballı, Ö. (2006). Bruınınks-oseretsky motor yeterlik testinin geçerlik, güvenirlik çalışması ve beş-altı yaş grubu çocuklara uygulanan cimnastik eğitim programının motor 
gelişime etkisinin incelenmesi (Doctoral thesis, Ankara University Institute of Science and Technology, Ankara).

Mülazımoğlu Ballı, Ö., \& Hürmeriç Altınsöz, I. (2019). Çocuklarda algılanan motor yeterlilik envanterinin Türkçe' ye uyarlama çalışması. Conference: VIth International Eurasian Educational Research Congress. Retrieved from https://ejercongress.org

Newell, K. M. (1991). Motor Skill Acquisition. Annu. Rev. Psychol., 42, 213-237. https://doi.org/10.1146/annurev.ps.42.020191.001241

NSES. (2000). Inquiry and the national science education standards: A guide for teaching and learning. Center for Science, Mathematics, and Engineering Education (CSMEE). Retrieved from http://www.nap.edu/openbook.php?record_id=9596\&page=1

Østergaard, L. D. (2016). Inquiry-based learning approach in physical education: Stimulating and engaging students in physical and cognitive learning. Journal of Physical Education, Recreation \& Dance, 87(2), 7-14. https://doi.org/10.1080/07303084.2015.1119076

Østergaard, L. D. (2019). Creation of new routines in physical education: second-order reflection as a tradition-challenging form of reflection stimulated by inquiry-based learning, Sport, Education and Society, 24(9), 981-993. https://doi.org/10.1080/13573322.2018. 1508012

Özkara, A. B., \& Kalkavan, A. (2018). Çocuk beden koordinasyon testinin ortaokul grubu Türk çocukları için geçerlik ve güvenirlik çalışması. Spormetre, 16(4), 1-11. https://doi.org/ 10.1501/Sporm_0000000389

Panasan M., \& Nuangchalerm P. (2010) Learning Outcomes of Project-Based and Inquiry-Based Learning Activities. Journal of Social Sciences, 6(2), 252-255. https://doi.org/ $10.3844 /$ jssp.2010.252.255

Parim, G. (2009). İlköğretim 8. sınıf ögrencilerinde fotosentez, solunum kavramlarının ögrenilmesine, başarıya ve bilimsel süreç becerilerinin geliştirilmesinde araştırmaya dayalı ögrenmenin etkileri (Doctoral thesis, Marmara University Institute of Educational Sciences, Istanbul).

Purichia, H. (2015). Problem-based learning: An inquiry approach. Interdisciplinary Journal of Problem Based Learning, 9(1). https://doi.org/10.7771/1541-5015.1522

Samaha, Y. (2019). La démarche d'investigation dans l'enseignement de la physiologie au niveau universitaire: Son effet sur l'acquisition de la notion du fonctionnement musculaire chez les étudiants en lère année d'éducation physique et sportive (Unpublished Master's thesis, Unıversite Libanaise, Faculté de Pédagogie).

Secker C. V. (2002). Effects of inquiry-based teacher practices on science excellence and equity. The Journal of Educational Research, 95(3), 151-160. https://doi.org/10.1080/ 00220670209596585 
Sevimay, D. (1986). Okul öncesi çă̆ çocuklarının motor performanslarının incelenmesi (Master's thesis, Hacettepe University Institute of Health Sciences, Ankara).

Soytürk, M., Birsen, Ş., \& Çamliyer, H. (2017). İlköğretim 6. ve 7. sınıf öğrencilerinde taktiksel oyun yaklaşımının problem çözme becerilerine etkisi. 4. Uluslararası Balkan Spor Bilimleri Kongresi (Oral Presentation). Bursa, Turkey.

Spessato, B. C., Gabbard, C., Valentini, N., \& Rudisill, M. (2013) Gender differences in Brazilian children's fundamental movement skill performance. Early Child Development and Care, 183(7), 916-923. https://doi.org/10.1080/03004430.2012.689761

Stodden, D. F., Goodway, J. D., Langendorfer, S. J., Roberton, M. A., Rudisill, M. E., Garcia, C., \& Garcia, L. E. (2008). A Developmental perspective on the role of motor skill competence in physical activity: An emergent relationship. Quest, 60(2), 290-306. https://doi.org/10.1080/00336297.2008.10483582

Taştepe, T., \& Köksal Akyol, A. (2018). 36-47 aylık çocuklarda peabody motor gelişim ölçeği-2'nin uyarlama çalışması ve motor gelişimin incelenmesi. Millî Eğitim Dergisi, 48(223), 61-82. Retrieved from https://dergipark.org.tr/tr/pub/milliegitim/issue/48112/608632

Tatar, N. (2006). İlköğretim fen eğitiminde araştırma dayalı öğrenme yaklaşımının bilimsel süreç becerilerine, akademik başarıya ve tutuma etkisi (Doctoral thesis, Gazi University Institute of Educational Sciences, Ankara).

Tatar, N., \& Kuru, M. (2009). Fen eğitiminde araştırmaya dayalı öğrenme yaklaşımının akademik başarıya etkisi. Hacettepe Üniversitesi Ĕ̌itim Fakültesi Dergisi, 31, 147-158. Retrieved from https://dergipark.org.tr/tr/pub/hunefd/issue/7807/102404

Tepeli, K. (2007). Büyük kas becerilerini ölçme testi (BÜKBÖT)'nin Türkiye standardizasyonu (Unpublished Doctoral thesis, Social Sciences Institute, Selcuk University, Konya).

Tretter, T. R., \& Jones, M. G. (2003). Relationships between inquiry-based teaching and physical science standardized test scores. School Science and Mathematics, 103(7), 345-350. https://doi.org/10.1111/j.1949-8594.2003.tb18211

Ulutaş, A., Demir, E., \& Yayan, E. H. (2017). Motor gelişim eğitim programının 5-6 yaş çocukların kaba ve ince motor becerilerine etkisinin incelenmesi. Abant İzzet Baysal Üniversitesi Ĕ̈itim Fakültesi Dergisi, 17(3), 1523-1538. https://doi.org/10.17240/aibuefd. 2017.17.31178-33884

Usher, W., Edwards, A., \& de Meyrick B. (2015). Utilizing educational theoretical models to support effective physical education pedagogy, Cogent Education, 2(1), 1094847. https://doi.org/10.1080/2331186X.2015.1094847

Uzunosmanoğlu, E., Gursel, F., \& Arslan, F. (2012). The effect of inquiry-based learning model on health-related fitness. Procedia - Social and Behavioral Sciences, 47, 1906-1910. https://doi.org/10.1016/j.sbspro.2012.06.921 
Wrotniak, B. H., Epstein, L. H., Dorn, J. M., Jones, K. E., \& Kondilis, V. A. (2006). The relationship between motor proficiency and physical activity in children. Pediatrics, 118(6), 1758-1765. https://doi.org/10.1542/peds.2006-0742

\section{Copyright Disclaimer}

Copyright for this article is retained by the author(s), with first publication rights granted to the journal.

This is an open-access article distributed under the terms and conditions of the Creative Commons Attribution license (http://creativecommons.org/licenses/by/3.0/). 